\title{
Mineral dust variability in central West Antarctica associated with ozone depletion
}

\author{
M. Cataldo ${ }^{1}$, H. Evangelista ${ }^{1}$, J. C. Simões ${ }^{2}$, R. H. M. Godoi ${ }^{3}$, I. Simmonds ${ }^{4}$, M. H. Hollanda ${ }^{5}$, I. Wainer ${ }^{6}$, F. Aquino ${ }^{2}$, \\ and R. Van Grieken ${ }^{7}$ \\ ${ }^{1}$ LARAMG, Universidade do Estado do Rio de Janeiro (Uerj), Pav. Haroldo L. Cunha/Subsolo, \\ Rua São Francisco Xavier 524, Maracanã, 20550-013, Rio de Janeiro, RJ, Brazil \\ ${ }^{2}$ Centro Polar e Climático, Instituto de Geociências, UFRGS, Av. Bento Goncalves 9500, 91501-970, \\ Porto Alegre, RS, Brazil \\ ${ }^{3}$ Environmental Engineering Department, Federal University of Paraná (UFPR) 19011, 81531-990, Curitiba, \\ PR, Brazil \\ ${ }^{4}$ School of Earth Sciences, University of Melbourne, 3010, Victoria, Australia \\ ${ }^{5}$ Instituto de Geociências, Universidade de São Paulo (USP), Rua do Lago 562, 05508-080, São Paulo, SP, Brazil \\ ${ }^{6}$ Departamento de Oceanografia Física, IO, Universidade de São Paulo USP, Praça do Oceanográfico 191, 05508-120, \\ São Paulo, SP, Brazil \\ ${ }^{7}$ Micro and Trace Analysis Centre, Department of Chemistry, University of Antwerp, 2610, Antwerp, Belgium \\ Correspondence to: M. Cataldo (cataldomarcio@gmail.com)
}

Received: 17 November 2011 - Published in Atmos. Chem. Phys. Discuss.: 21 May 2012

Revised: 12 December 2012 - Accepted: 4 January 2013 - Published: 25 February 2013

\begin{abstract}
We present here data of mineral dust variability retrieved from an ice core of the central West Antarctic, spanning the last five decades. Main evidence provided by the geochemical analysis is that northerly air mass incursions to the coring site, tracked by insoluble dust microparticles, have declined over the past $50 \mathrm{yr}$. This result contrasts with dust records from ice cores reported to the coastal West Antarctic that show increases since mid-20th century. We attribute this difference to regional climatic changes due to the ozone depletion and its implications to westerly winds. We found that the diameters of insoluble microparticles in the central West Antarctica ice core are significantly correlated with cyclone depth (energy) and wind intensity around Antarctica.
\end{abstract}

\section{Introduction}

Since the mid-1980s the ozone depletion area in the Antarctic stratosphere in austral spring has exceeded 10 million $\mathrm{km}^{2}$ and has been recognized as a threat with direct implications to biogeochemical processes in the Antarctic environment (Zepp et al., 1998). Rapid chlorine catalyzed reactive cycles have been established as the cause of ozone depletion in Antarctica. Important players in chlorine-catalyzed ozone destruction are the anthropogenic chlorofluorocarbons (CFC) and polar stratospheric clouds (PSCs) (Solomon, 1999; Müller, 2009). Polar stratospheric clouds provide the surfaces for heterogeneous reactions, in particular between $\mathrm{HCl}$ and $\mathrm{ClONO}_{2}$, which are a prerequisite for chlorine catalyzed ozone loss (Solomon et al., 1986). Moreover, greenhouse gases that warm the Earth's surface but cool the stratosphere radiatively, become also a critical factor since chemical reactiveness of ozone is highly sensitive to lowering temperatures (e.g. Shindell et al., 1998; Vogel et al., 2011). Recently it has been argued that the ozone depletion has climatic consequences (Arblaster and Meehl, 2006; Arblaster et al., 2011). Stratospheric cooling due to ozone depletion may strengthen the Antarctic circumpolar vortex during the austral spring season. This is consistent with the observed downward trends in tropospheric geopotential height and air temperature (Keeley et al., 2007), which suggests a propagation of this influence to lower levels. The relative cooling of the Antarctic stratosphere contrasts with a warming surrounding troposphere attributed to greenhouse gas emissions. 
This thermal gradient strengthens the westerly jets as well as the westerly winds at the surface (Thompson et al., 2000).

The exceptional warming of the Antarctic Peninsula can be seen as a probable consequence of the stronger westerlies (Delworth et al., 2006) with concurrent more advection of marine moisture and heat flux from the South Pacific Ocean. Recent estimates of the Antarctic surface air temperature distribution derived from a diverse range of sources such as meteorological ground stations, radiosonde sounding profiles, geochemical proxies in ice cores and satellite measurements have highlighted a near-dipole thermal structure over Antarctica: warmer over West Antarctica, contrasting to slightly cooling (and nearly stable) climatological conditions over central and East Antarctica (Steig et al., 2009; O'Donnell et al., 2011). In part such differences have been attributed to the non-annular atmospheric circulation change induced by the stratospheric ozone depletion that strengthens autumn winds around the continent, deepening the Amundsen Sea low through flow separation around the high coastal orography (Turner et al., 2009). In addition to predictions from numerical models and trends in meteorological databases, evidence of climatic changes in Antarctica can be also provided by the interpretation of geochemical proxies retrieved from ice cores and from the very few long-term aerosol monitoring programs. Interpretation of dust deposits in Antarctic ice cores has been connected to atmospheric transport strength and source availability of dust in the surrounding continents (Basile et al., 1997; Li et al., 2010).

Recent ice-coring projects conducted in West Antarctica revealed the impact of the increasing westerlies on air mass incursions and dust deposition at that sector: one conducted at James Ross Island (JRI)/Northeast Antarctic Peninsula (McConnell et al., 2007) and a second at Marie Byrd Land (MBL) (Dixon et al., 2013). Both have revealed pronounced increases of dust concentrations during the ozone depletion decades. Aluminosilicate levels recorded at JRI more than doubled along the 20th century, concomitant not only to widespread desertification in Argentine Patagonian semidesert (McConnell et al., 2007) but also increasingly westerly winds. A similar behavior was observed at MBL, employing the $\mathrm{nssCa}^{2+}$ as terrigenous proxy of northerly air mass incursions (Dixon et al., 2013).

Besides the surface winds, cyclones were identified as very efficient systems involved in the transport of dust materials to Antarctica (Law et al., 1992). Evangelista and Pereira (2002) demonstrated that the effectiveness of dust apportioning the Antarctic Peninsula from Patagonia is well related to the frequency and radius of cyclones at that site. At Talos Dome, the Southern most interface of western Antarctica, the 20th century record of dust concentrations showed marked increments around the 1930s, followed by two decades of reduction and a second increase after the 1960s to the top of the record (Sala et al., 2008). The authors argued that the increased soluble dust record and mean March-to-November
500 mbar geopotential height at that site were likely associated with enhanced cyclonic conditions.

Ice-core geochemistry combined with atmospheric dispersion models has improved the understanding of mineral dust reaching Antarctica. Quantitatively, the dust in Southern Hemisphere originates primarily from Australia, $\left(\sim 120 \mathrm{Tg} \mathrm{a}^{-1}\right)$ followed by Patagonia $\left(\sim 38 \mathrm{Tg} \mathrm{a}^{-1}\right)(\mathrm{Li}$ at al., 2008). Although fluxes are quite different, it is estimated that South America and Australia would contribute about equally to the total dust burden and deposition in the Southern Ocean and Antarctica due to prevailing westerly wind patterns, meridional fluxes, and the continental distances involved. Modeling approaches have revealed that the transport of Patagonian dust to Antarctica is essentially derived from the San Julian's Great Depression region, located inside the semi-desert domain (Li et al., 2010). Another potential dust source in South America can be the Bolivian Altiplano (Prospero et al., 2002). Its present-day dust activity sources are attributed to late Pleistocene lakes that filled vast areas of the Altiplano. The influence of these dust sources protrude in different sectors of Antarctica's interior. The southward flow of Patagonian semi-desert tends to hit the Antarctic continent on its west side at the Antarctic Peninsula and Ellsworth Land, and on its east side from Dronning Maud Land to approximately Princess Elizabeth Land at the Indian Ocean coast. In contrast, the influence of Australian dust predominates in Victoria Land and part of Mary Byrd Land (Li et al., 2008).

In this work we present analysis of Mount Johns (MJ) ice core $\left(79.55^{\circ} \mathrm{S}, 94.23^{\circ} \mathrm{W}\right)$, with a view to investigating the incursion of mineral dust to central West Antarctica during the ozone depletion evolution period. The location of Mount Johns is particularly valuable in this respect as that site receives air mass influences from both East and West Antarctica, according to surface wind streamlines patterns proposed by Parish and Bromwich (2007). To support our analyses and interpretation, we have derived a number of aspects of the subantarctic atmospheric circulation and cyclone characteristics since 1958.

\section{Methodology}

\subsection{Ice-core retrieval and (radio) isotopic analysis}

Drilling was conducted at $\mathrm{MJ} /$ central West Antarctica in December 2007 making use of an electro-mechanical driller with a maximum extraction depth of $160 \mathrm{~m}$. The top $40-\mathrm{m}$ ice core, of $9 \mathrm{~cm}$ in diameter, was divided into 45 segments ranging from 85 to $95 \mathrm{~cm}$ in the field, where density measurements were performed. The MJ ice core was maintained frozen $\left(-20^{\circ} \mathrm{C}\right)$ until laboratory analyses started in Rio de Janeiro State University, Brazil. Sub-sampling was conducted aiming to determinate the deuterium/hydrogen $(\mathrm{D} / \mathrm{H})$ ratios, gamma radioactivity and elemental/molecular micro-analysis by SEM-EDX 
(Scanning Electron Microscopes-Energy-dispersive X ray spectroscopy), as described below.

In clean laboratory conditions, an external layer of the core was removed with a teflon knife and the 45 core segments were all cut into slices of $10 \mathrm{~cm}$. The slices were separated into individual vials and melted at $4{ }^{\circ} \mathrm{C}$. Sub-samples of $5 \mathrm{~mL}$ were taken for stable isotope analysis. Subsequently, the rest of each ice-core segment was mixed in a beaker (cleaned with detergent followed by acid solution), comprising a volume of approximately $2 \mathrm{~L}$ per section. Each volume was filtered through a $0.1 \mu \mathrm{m}$ Nuclepore polycarbonate membrane. The 40-m ice core of $\mathrm{MJ}$ was dated by $\mathrm{D} / \mathrm{H}$ annual variability. Extractions of $\mathrm{D} / \mathrm{H}$ were performed in an automatic mass spectrometer (DeltaPlus Finningan/Thermo Advantage). A fraction of each liquid sample of $1 \mu \mathrm{L}$ was used. The international standards used were V-SMOW, IAEA-SLAP2 and IAEA-GISP2.

Each filtered sample segment of the ice core was firstly submitted to the non-destructive technique of high resolution gamma spectrometry. We have used an extended energy range co-axial hyperpure germanium (HPGe) detector with relative efficiency of $20 \%$ and resolution of $2.5 \mathrm{keV}$ at the ${ }^{137} \mathrm{Cs}$ energy peak. This detector is placed inside a 5-ton lead shield, ensuring a very low background. Detector efficiency was obtained using a liquid solution containing a cocktail of radionuclides - NIST (serial number HV951). The cocktail used in this study included the radionuclides ${ }^{133} \mathrm{Ba},{ }^{57} \mathrm{Co},{ }^{139} \mathrm{Ce},{ }^{85} \mathrm{Sr},{ }^{137} \mathrm{Cs},{ }^{54} \mathrm{Mn},{ }^{88} \mathrm{Y}$, and ${ }^{65} \mathrm{Zn}$. Details of this method are described in Handl et al. (2008). The net gamma ray spectrum was analyzed in the ${ }^{137} \mathrm{Cs}$ energy window, around $662 \mathrm{keV}$, and integrated counts were subtracted to $24 \mathrm{~h}$ background at the same energy window. The chronology of the ice core was confirmed by the detection of ${ }^{137}$ Cs Chernobyl peak of 1986 coincident to same date inferred by the D/H. A similar marker was previously detected at the South Pole (Dibb et al., 1990).

\subsection{Single particle analysis}

SEM-EDX sample analyses were performed using a JEOL 6300 Scanning Electron Microscope (JEOL ${ }^{\mathrm{TM}}$, Tokyo, Japan) equipped with backscattered and secondary electron detectors and an EDX detection system at University of Antwerp, Belgium. A Si(Li) X-ray detector coupled to a PGT system (Princeton Gamma Tech, Princeton, NJ, USA), was employed for acquiring the X-ray spectra. Particles collected in Nuclepore substrates provided good contrast between the backscattered electron signals (BSE) from the particles and those from the substrate. The electron beam scans the samples, and when the measured backscattered electron signal is higher than a pre-set threshold value, a particle is considered to be detected. When the contours of the located particle are ascertained, the morphology (shape factor) and size (geometric equivalent diameter) are determined. The elemental detection limits of the SEM-EDX are around $1 \%$ in mass. The control software localizes the particles from the BSE image and performs an X-ray measurement within each particle. The intensities of the characteristic peaks in the spectra were determined by the top-hat filter method that stresses regions of high gray intensities (Van Espen and Janssens, 1992). In all samples, 400 individual particles were analyzed for each filter. Following the SEM-EDX analysis, only those variables (elements) detected in more than $1 \%$ of the analyzed particles were considered. In our case, they were the following: $\mathrm{Na}, \mathrm{Mg}, \mathrm{Al}, \mathrm{Si}, \mathrm{P}, \mathrm{S}, \mathrm{Cl}, \mathrm{K}, \mathrm{Ca}, \mathrm{Ti}, \mathrm{V}, \mathrm{Cr}, \mathrm{Mn}, \mathrm{Fe}, \mathrm{Ni}, \mathrm{Cu}, \mathrm{Zn}$ and $\mathrm{Pb}$; besides the diameter estimate and the sump (sum of the characteristic lines in the X-ray spectrum). The database of the elemental composition was submitted to a hierarchical cluster analysis, based on the Forgy algorithm (Anderberg, 1973), in order to classify the particles structures. In this method, each particle is a point in a multidimensional space where each coordinate or dimension is the concentration of an element. Particles that are close to each other or have similarities between them are combined into a new group. This process is continuous and forms new groups until all particles are combined into sub-groups or end groups presented as dendrograms. The number of final groups is defined using the Akaike criterion, which is based on the relationship between the order of a system and its minimum entropy (Bondarenko et al., 1996; Hoornaert et al., 2004). The 45 samples were analyzed following an instrumental setup defined as: accelerating voltage of $20 \mathrm{keV}$, current of $1 \mathrm{nA}$, X-ray spectrum acquisition time of $20 \mathrm{~s}$, image magnification of $1000 \mathrm{x}$ and range of diameter analyzed $0.7-20 \mu \mathrm{m}$. Particles containing the elements $\mathrm{Cl}, \mathrm{Cr}, \mathrm{Cu}, \mathrm{Ni}, \mathrm{S}, \mathrm{W}$ and $\mathrm{V}$ corresponded to $2 \%$ of the total. Hierarchic analysis have revealed 34 groups or clusters. The six most abundant clusters occurred in $70 \%$ of the samples. Our results are based on the elements that can be detected by conventional automated SEM-EDX technique, excluding elements with an atomic number lower than 11 such as $\mathrm{C}, \mathrm{N}$ and $\mathrm{O}$.

\subsection{Climate and meteorological databases}

The basic aim of this work is to investigate the mineral dust variability (fraction of insoluble dust and diameter) at MJ with respect to changes in the atmospheric circulation, and particularly wind and cyclone dynamics. To undertake this, we make use of both ground-based meteorological data and the NCEP-NCAR reanalysis (Kalnay et al., 1996) for the period 1958-2009. These reanalyses applied modern assimilation procedures to historical data, and provide the most comprehensive and consistent picture of the four-dimensional structure of the global atmosphere over the selected period (Simmonds, 2003). In data-sparse regions, the introduction of new data at a given time into the assimilating model can produce analyses which appear to have jumps or trends. A case in point is the widespread use in analysis schemes of satellite data starting in 1979 (Hines et al., 2000; Simmonds and King, 2004; Bromwich et al. 2007). However, we take 

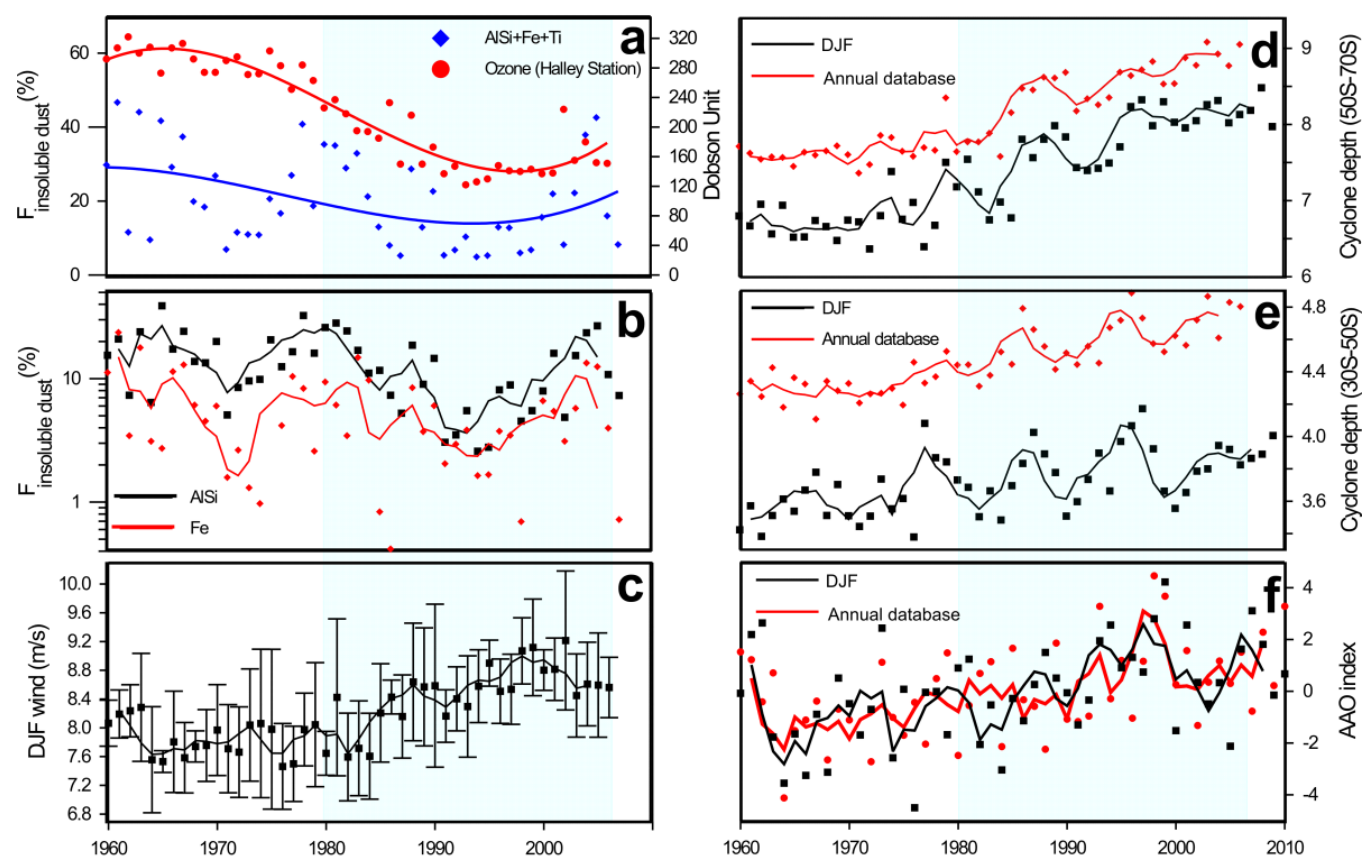

Fig. 1. (a) Fraction of insoluble dust microparticles ( $\mathrm{AlSi}+\mathrm{Fe}+\mathrm{Ti})$ at Mount Johns and ozone concentrations measured for October at Halley Bay Antarctic Stations (both with polynomial trends of degree 3 overlaid); (b) fraction of insoluble dust microparticles for AlSi and Fe, individually; (c) DJF wind intensity for $40-70^{\circ} \mathrm{S}$ (error bar: 1 standard deviation); (d) cyclone depth for DJF and the annual databases for the latitudinal bands $50-70^{\circ} \mathrm{S}$ and, (e) the same for $30-50^{\circ} \mathrm{S}$; and (f) for AAO index. Shaded areas highlight the period of depleted ozone scenario.

the perspective that it is of considerable value to use the NCEP-NCAR reanalysis prior to this time as it provides a broader view of the changes which have occurred over the last half century. In our investigation we are particularly interested in subantarctic cyclone characteristics. In the International Geophysical Year (1957-8), many radiosonde stations were established around the periphery of the Antarctic continent, taking quality atmospheric soundings at high temporal frequency. In toto these stations are able to provide a good picture of subantarctic surface cyclone activity, and for this reason we are comfortable, with certain caveats, in using the data back to 1958 .

From the 6-hourly NCEP-NCAR global mean sea level pressure fields we locate the cyclones using the algorithm of Lim and Simmonds (2007). In addition to finding cyclones, the algorithm also determines the morphological properties of each cyclone it identifies. One of these properties which is of particular relevance to the present investigation is the "depth" of a cyclone, which is the difference between the pressure at the edge of the cyclone and the pressure at the center. In the idealized case of an axi-symmetric cyclone, this can be written as $1 / 4\left(R^{2} \nabla^{2} p\right)$ (Simmonds et al., 2008), where $R$ is the cyclone radius and $p$ is the mean sea level pressure). This metric provides direct information of the effect of a cyclone on the environment (and possibly the transport of terrigenous tracers) in that it is proportional to the total eddy flux affected by a cyclone (Simmonds and Keay, 2000 ) and to the total kinetic energy of the cyclone (Simmonds et al., 2008), a consideration essential to our argument here.

\subsection{Cluster analyses of databases}

Considering the wide range of parameters (of geochemistry and climate nature) employed in this work, we have conducted a hierarchical cluster analysis in order to investigate the similarity level among them. In this case we have used the single linkage algorithm as the agglomerative hierarchical clustering method and Pearson's $r$ correlation as the similarity measure (Digby and Kempton, 1987). Pearson's $r$ correlation measure reflects the degree of closeness of objects defined with the formula $d=1-r$, where $d$ is the distance, $r=Z(x) \cdot Z(y) / n$ is the dot product of the z-scores of the vectors $\boldsymbol{x}$ and $\boldsymbol{y}$. The z-score of $\boldsymbol{x}$ is constructed by subtracting from $\boldsymbol{x}$ its mean and dividing by its standard deviation. In cluster analyses, the single linkage (or the nearest neighbor) is a method of calculating distances between clusters in a way that the distance between two clusters is defined as the distance between the two closest elements in the two clusters. The result is summarized as a dendrogram that depicts how the clusters are merged hierarchically. 
Table 1. Trends in surface wind intensity measured in Antarctic stations (maritime region) before and after 1979. Data compiled from the SCAR-READER database. "Increase" and "Decrease", (+/-), refer to trends.

\begin{tabular}{lllrrrr}
\hline Weather Station & Lat. & Long. & Height & \multicolumn{2}{c}{ Wind intensity $\left(\mathrm{m} \mathrm{s}^{-1}\right)$} & Increase $(+)$ \\
\cline { 4 - 6 } Around Antarctica & & & Before 1979 & After 1979 & Decrease $(-)$ \\
\hline Bellingshausen & $62.2^{\circ} \mathrm{S}$ & $58.9^{\circ} \mathrm{W}$ & 16 & $14.0 \pm 2.2(68-79)$ & $14.4 \pm 2.0(80-10)$ & + \\
Campbell & $52.0^{\circ} \mathrm{S}$ & $169.0^{\circ} \mathrm{E}$ & 19 & $17.4 \pm 2.6(61-79)$ & $16.2 \pm 2.5(80-10)$ & - \\
Casey & $66.3^{\circ} \mathrm{S}$ & $110.5^{\circ} \mathrm{E}$ & 42 & $11.9 \pm 3.6(60-79)$ & $13.6 \pm 3.9(80-90)$ & + \\
Davis & $68.6^{\circ} \mathrm{S}$ & $78.0^{\circ} \mathrm{E}$ & 13 & $9.9 \pm 2.3(57-79)$ & $11.0 \pm 2.4(80-10)$ & + \\
Durmont d'Urville & $66.7^{\circ} \mathrm{S}$ & $140.0^{\circ} \mathrm{E}$ & 43 & $20.6 \pm 4.3(56-79)$ & $18.2 \pm 3.6(80-10)$ & - \\
Esperanza & $63.4^{\circ} \mathrm{S}$ & $57.0^{\circ} \mathrm{W}$ & 13 & $16.2 \pm 6.5(57-78)$ & $14.7 \pm 4.1(80-10)$ & - \\
Faraday/Vernadsky & $65.4^{\circ} \mathrm{S}$ & $64.4^{\circ} \mathrm{W}$ & 11 & $7.6 \pm 2.6(50-79)$ & $8.9 \pm 2.5(80-10)$ & + \\
Grytviken & $54.3^{\circ} \mathrm{S}$ & $36.5^{\circ} \mathrm{W}$ & 3 & $8.6 \pm 2.0(59-79)$ & $8.9 \pm 1.6(01-10)$ & + \\
Halley & $75.5^{\circ} \mathrm{S}$ & $26.4^{\circ} \mathrm{W}$ & 30 & $13.3 \pm 3.4(57-79)$ & $12.2 \pm 2.9(80-10)$ & - \\
Leningradskaja & $69.5^{\circ} \mathrm{S}$ & $159.4^{\circ} \mathrm{E}$ & 304 & $16.3 \pm 3.0(71-79)$ & $15.8 \pm 2.9(80-91)$ & - \\
Macquarie & $54.5^{\circ} \mathrm{S}$ & $158.9^{\circ} \mathrm{E}$ & 8 & $17.0 \pm 2.8(48-79)$ & $18.4 \pm 2.5(80-10)$ & + \\
Marambio & $64.2^{\circ} \mathrm{S}$ & $56.7^{\circ} \mathrm{W}$ & 198 & $19.5 \pm 4.8(71-79)$ & $17.1 \pm 4.0(80-10)$ & - \\
Marsh & $62.2^{\circ} \mathrm{S}$ & $58.9^{\circ} \mathrm{W}$ & 10 & $12.7 \pm 2.2(70-79)$ & $14.8 \pm 3.5(80-10)$ & + \\
Mawson & $67.6^{\circ} \mathrm{S}$ & $62.9^{\circ} \mathrm{E}$ & 16 & $21.8 \pm 4.2(54-79)$ & $22.1 \pm 4.2(80-10)$ & + \\
McMurdo & $77.9^{\circ} \mathrm{S}$ & $166.7^{\circ} \mathrm{E}$ & 24 & $11.5 \pm 2.6(56-79)$ & $9.8 \pm 2.0(80-10)$ & - \\
Mirny & $66.5^{\circ} \mathrm{S}$ & $93.0^{\circ} \mathrm{E}$ & 30 & $22.4 \pm 4.7(56-79)$ & $21.8 \pm 4.3(80-10)$ & - \\
Molodeznaja & $67.7^{\circ} \mathrm{S}$ & $45.9^{\circ} \mathrm{E}$ & 40 & $19.8 \pm 6.1(63-79)$ & $20.8 \pm 6.2(80-99)$ & + \\
Novolazarevskaya & $70.8^{\circ} \mathrm{S}$ & $11.8^{\circ} \mathrm{E}$ & 119 & $19.8 \pm 6.1(63-79)$ & $20.8 \pm 6.2(80-99)$ & + \\
Orcadas & $60.7^{\circ} \mathrm{S}$ & $44.7^{\circ} \mathrm{W}$ & 6 & $12.2 \pm 4.3(56-79)$ & $12.6 \pm 2.3(80-10)$ & + \\
Rothera & $67.5^{\circ} \mathrm{S}$ & $68.1^{\circ} \mathrm{W}$ & 32 & $11.3 \pm 2.8(76-79)$ & $12.1 \pm 3.0(80-10)$ & + \\
Signy & $60.7^{\circ} \mathrm{S}$ & $45.6^{\circ} \mathrm{W}$ & 6 & $13.8 \pm 3.0(56-69)$ & $14.9 \pm 3.0(84-95)$ & + \\
Syowa & $69.0^{\circ} \mathrm{S}$ & $39.6^{\circ} \mathrm{E}$ & 21 & $11.6 \pm 3.6(57-79)$ & $12.9 \pm 3.6(80-05)$ & + \\
\hline & & & & & & + \\
\hline
\end{tabular}

\section{Results and discussions}

Although mineral dust records in ice cores of West Antarctica have provided evidence of potential climate effects due to ozone depletion, the same has not been recognized for central western Antarctica, a region that we understand as "atmospheric isolated". Climate changes attributed to the ozone depletion over the Southern Ocean is one of the conclusive topics at the Executive Summary WMO/UNEP - "Scientific Assessment of Ozone Depletion: 2010", prepared by the Scientific Assessment Panel of the Montreal Protocol on Substances that Deplete the Ozone Layer (http://montreal-protocol.org/Assessment Panels/SAP/ExecutiveSummary_SAP_2010.pdf). Therefore the parameter "ozone depletion" is assumed here as a potential cause of the recent atmospheric circulation change ongoing around Antarctica during the last decades and a factor able to modulate the inflow of mineral dust into Antarctica. Ozone data presented here are measurements taken during October at Halley Antarctic station (Farman et al., 1985; Jones et al., 1995), whose database shows a very similar behavior of total ozone as South Pole station (Solomon, 1999). At that site observed ozone content was $\sim 30 \%$ lower in the spring seasons (October) of 1980-1984 than in the springs of 1957-1973, Solomon et al. (1986). The issue of the seasonality of ozone changes is complex. Further there is still no clear consensus on which aspect of the seasonality of ozone is the most important. For example, Keeley et al. (2007) comment that stratospheric ozone depletion peaks in October-November, whereas tropospheric trends are largest in December-January, concurrent with maximum ozone changes close to the tropopause. Surface temperatures are most sensitive to ozone loss near the tropopause. It has been suggested that the observed tropospheric response is forced mainly by ozone depletion in the lower stratosphere. In our samples, $53 \%$ of the total particles counted $(n=17600)$ have presented the elements $\mathrm{Si}, \mathrm{Al}, \mathrm{Fe}$ and $\mathrm{Ti}$ as main constituents. The method allows differentiating microparticle compositions individually in the sample insoluble fraction. Therefore, our data refer to the "fraction of insoluble dust microparticles containing enriched AlSi and $\mathrm{Fe}$ " $\left(F_{\text {insoluble dust }}\right)$ with respect to the total detected insoluble microparticles, which exclude all sea-salt compounds in the sample. Insoluble elements/compounds detected were $\mathrm{Al}$, $\mathrm{Cr}, \mathrm{Cu}, \mathrm{Fe}, \mathrm{Ni}, \mathrm{S}, \mathrm{Si}, \mathrm{Ti}, \mathrm{W}, \mathrm{V}, \mathrm{AlSi}, \mathrm{AlTi}, \mathrm{AlSi}-\mathrm{Cl}, \mathrm{AlSi}-\mathrm{Fe}$, AlSi-Mg, AlSi-S, AlSi-Ti, AlSi/FeCl, Fe-Cr, FeSi, FeSi-S, Fe-Cr-W, KCl, SiCl, SiS, SiS Cu, SZn, TiSi, V-Cr, V-Fe, V $\mathrm{Cr}, \mathrm{Fe} \mathrm{W}$ and $\mathrm{V} \mathrm{Cr} \mathrm{Si}$. Time series for mineral dust were denoted by $F_{\mathrm{AlSi}+\mathrm{Fe}+\mathrm{Ti}}$ (Fig. 1a), where the insoluble dust microparticles have presented similar trends with respect to ozone depletion mainly after the 1980s (Fig. 1b). The regression between ozone and dust at Mount Johns corresponded 


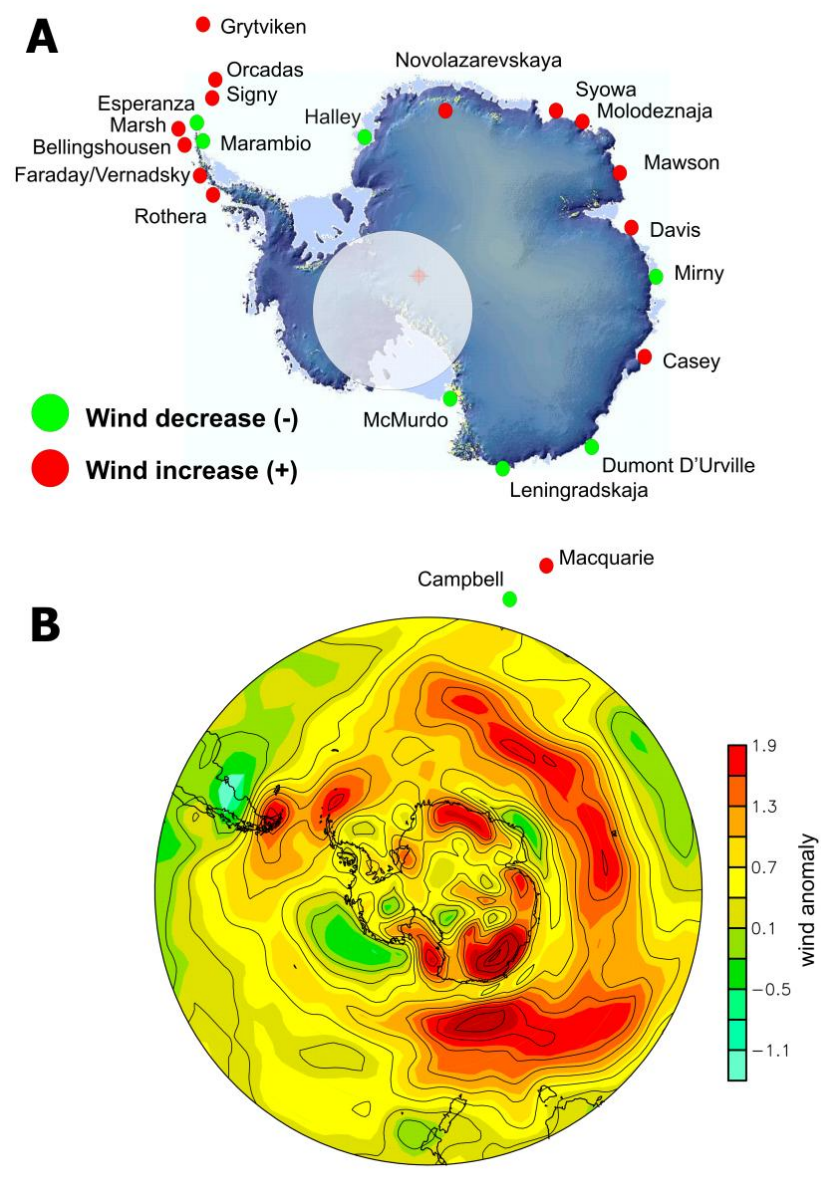

Fig. 2. (A) Surface wind trends from Antarctic stations before and after 1979 (see Table 1); and (B) for comparison, simulated wind anomaly by NCEP-NCAR reanalysis relative to 1979 at $925 \mathrm{hPa}$.

to Pearson's $r$ equal to +0.46 , which is statistically significant at $95 \%$ confidence level, considering the two-sided Student's t-significance test, as $t=\left\{r(n-2)^{1 / 2} /\left(1-r^{2}\right)^{1 / 2}\right\}$ and $n=44$. Prior to the satellite era, climate reanalysis data for Antarctica should mostly be interpreted as reliable for the summer months window (December, January and February - DJF), Bromwich et al. (2007). Accordingly, wind data depicted in Fig. 1c pertain only to the austral summer months (DJF) with 1 standard deviation bars. It is clear that inverse trends between NCEP DJF winds around Antarctica (Fig. 1c) and ozone depletion, AlSi and Fe were evidenced.

The mean cyclone depth was calculated for all cyclones in the $50-70^{\circ} \mathrm{S}$ (Fig. 1d) and 30-50 $\mathrm{S}$ (Fig. 1e) latitude belts. In addition to the DJF data, we have preserved the cyclone annual time series in Fig. 1 since the mineral dust microparticles data in the ice core is of annual resolution. Particularly at $50-70^{\circ} \mathrm{S}$, the increase of cyclone depth is clearly observed. An inspection at Fig. 1d and e indicates that cyclone depth increased significantly after the 1980s, which coincides with ozone depletion evolution. Therefore, mid-to-sub-Antarctic zones have been experiencing increasingly westerlies com-

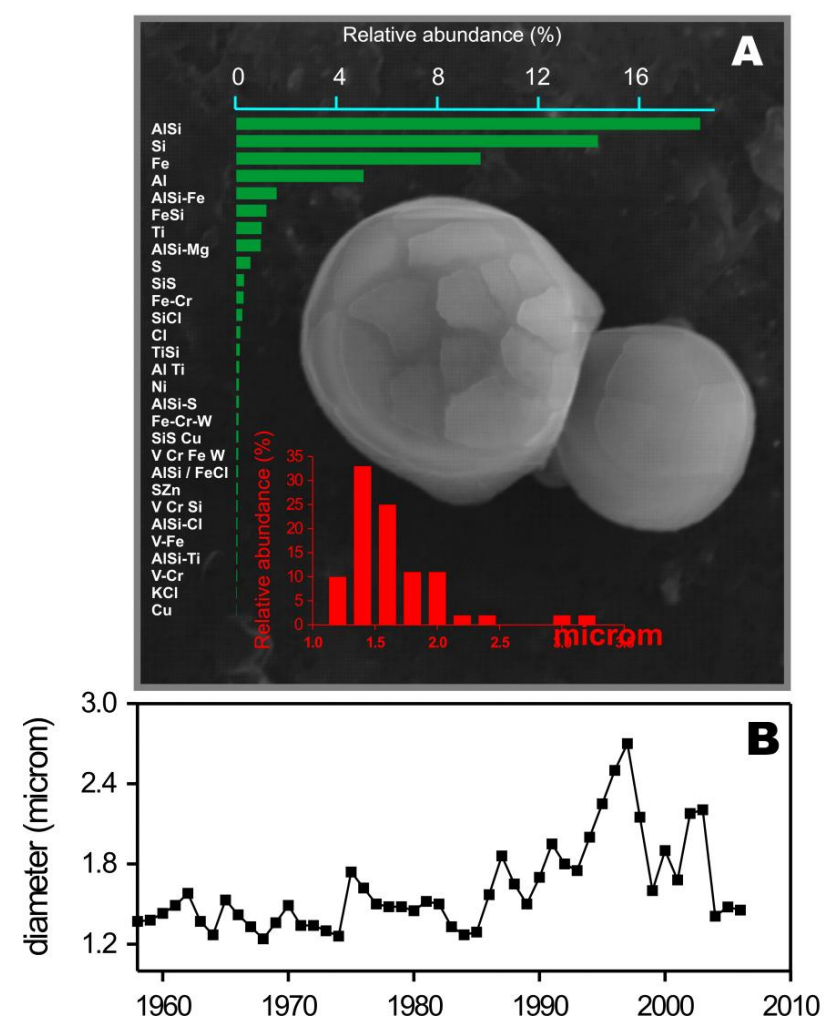

Fig. 3. (A) Size distribution of insoluble microparticles and relative abundance of elements/chemical compounds obtained for Mount Johns ice core (central West Antarctica); (B) time variability of microparticle diameters at the same site.

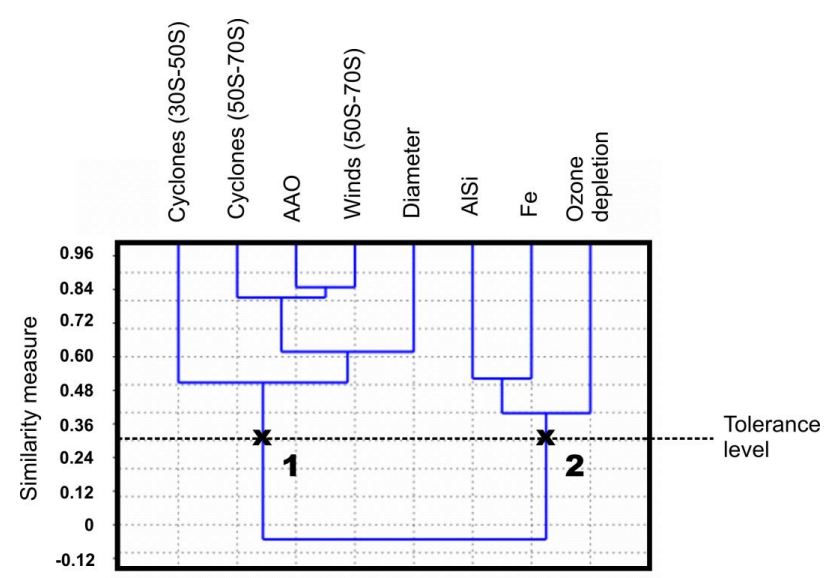

Fig. 4. Dendrogram showing the similarity level among the geochemical and climate parameters. In this case the algorithm used is the single linkage, and Pearson's $r$ correlation was the similarity measure. A tolerance level defined around 0.3 grouped 2 sets of parameters.

bined with increasing cyclone activity. This presents a favorable scenario for mineral dust delivery to the atmosphere surrounding Antarctica. 

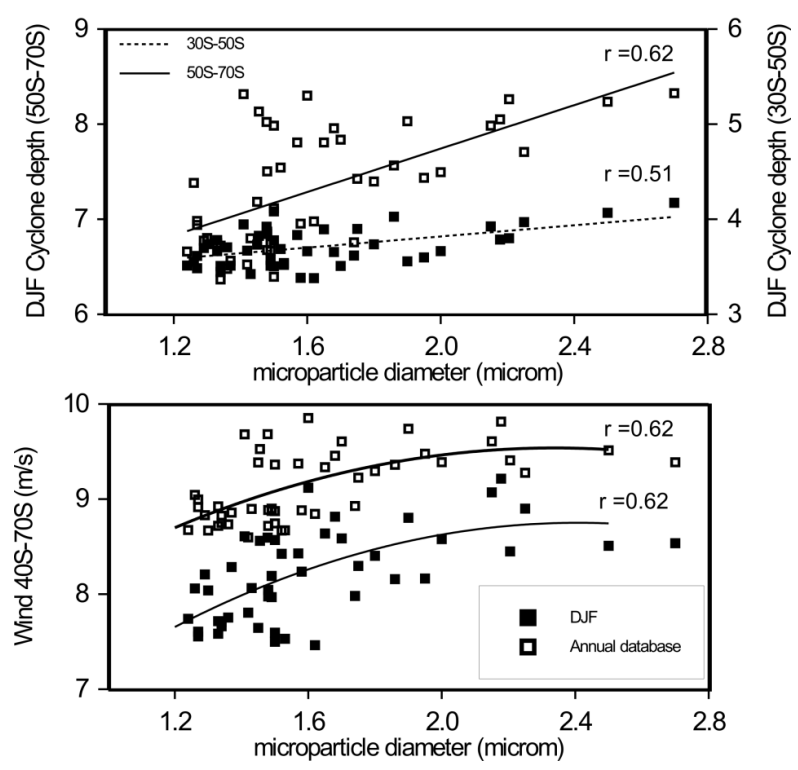

Fig. 5. (upper) Correlation between total insoluble microparticle diameter in Mount Johns ice core and DJF cyclone depth around Antarctica between 1960 and 2007; (bottom) the same as the previous, but for wind intensity $\left(40-70^{\circ} \mathrm{S}\right)$. A quadratic model was used to the best fit of the wind correlation.

Additionally, one may observe the similar ascending behavior of cyclone depth (Fig. 1d, e) and the positive phase of the Antarctic Oscillation index, AAO (Fig. 1f). The positive phase of AAO index is persistent after the 80 s and may generate more and stronger cyclones at high southern latitudes (Pezza et al., 2008). The AAO index data presented here are from an observation-based Southern Hemisphere annular mode index (http://www.antarctica.ac.uk/met/gjma/ sam.html, last revised in October 2011). In this definition 12 stations were used to compose the zonal means from $40^{\circ} \mathrm{S}$ to $65^{\circ} \mathrm{S}$ (Marshall, 2003). Several studies have examined the impacts of changes in the AAO with regard to the atmosphere (Hendon et al., 2007), sea ice (Hall and Visbeck, 2002; Lefebvre et al., 2004) and ocean circulation (Sen Gupta and England, 2006). The intensification of the westerlies in conjunction with the positive trend of the AAO has been documented in observations, reanalysis and climate model simulations from the mid-1960s to present (Thompson and Solomon, 2002; Marshall, 2007; Visbeck, 2009). The positive phase of the AAO can also be related to changes in the meridional temperature gradient associated with the cooling of the polar lower stratosphere, attributed to ozone depletion. This is accompanied by warming in the tropical upper troposphere which is, besides global warming, related to an increased vertical gradient of the wind in the mid-latitude tropopause region also affecting the tropospheric winds.

Uncertainty in our knowledge of the spatial variability of meteorological parameters in the region south of $40^{\circ} \mathrm{S}$, before ozone depletion occurred $(\sim 1979)$, is quite large, and the marine coverage is very seasonally biased. Considering this uncertainty, we support our findings on the basis of the wind intensity of selected weather stations located at (or near) the maritime Antarctic whose meteorological databases comprise the period before and after 1979. These data are provided by the SCAR-READER at http://www.antarctica. ac.uk/met/READER/surface/stationwind.html. Table 1 encloses data of 22 Antarctic stations with data continuity large enough to accomplish the above requirement. Mean wind databases show increases in $64 \%$ of the stations after 1979. Although wind increases are not of statistical significance, they represent slight positive increments in the trends during the last decades.

Model simulations indicate that surface wind and windstress have increased significantly over the Southern Ocean after 1979 (Thompson and Solomon, 2002; Lenton et al., 2009; Swart and Fyfe, 2012). In Fig. 2 we have compared surface wind trends from ground stations with NCEP-NCAR reanalysis. An important observation raised from the comparison is that reanalyzed data did not reproduce the instrumental wind decreases observed in Campbell, Mirny and at those stations in the Weddell sector (Halley, Marambio and Esperanza). The same holds true for the coastal sector between Terre Adélie and the Ross Ice Shelf, which is different from the northern Antarctic Peninsula result where the model was particularly robust. In general the median difference (2010-1979 minus 1960-1979) of $+0.41 \mathrm{~m} \mathrm{~s}^{-1}$ derived from instrumental data, considering all stations at Table 1, was well reproduced.

The reduction of insoluble mineral dust in the central Antarctic atmosphere may have implications on annual snow accumulation. Decreases in accumulation between 1985 and 2001 inferred by the Polar MM5 mesoscale model (Monaghan et al., 2006a) are particularly obvious over the RonneFilchner ice shelf, part of Dronning Maud Land, and the coastal regions of East Antarctica. The efficiency of dust as cloud condensation nuclei $(\mathrm{CCN})$ has been previously demonstrated in controlled experimental conditions similar to those found at sites of the Polar Plateau (Monaghan et al., 2006b). Si-enriched microparticles found at MJ were predominantly spherical, Fig. 3a. This type of grain morphology is expected to exist in semi-arid sites (Rodriguez et al., 2009) and reflects the "aeolian weathering" due to successive collisions among grains at the source regions. Time variability of insoluble microparticle diameters show significant increase after 1985, ranging from $1.42 \pm 0.12 \mu \mathrm{m}$ to $1.87 \pm 0.35 \mu \mathrm{m}$ (Fig. 3b). The shift to larger dust microparticles in the Antarctic ice sheet was previously found in the Dome $\mathrm{C}$ ice core during episodes of more vigorous circulation from the tropics toward Antarctica (Petit et al., 1981).

The dendrogram obtained by the use of the single linkage as the amalgamation algorithm and Pearson's $r$ correlation as the similarity measure, Fig. 4, does corroborate our hypothesis that ozone depletion modulates the mineral dust inflow to Antarctica (Group 2 in the cluster analyses) and that the 

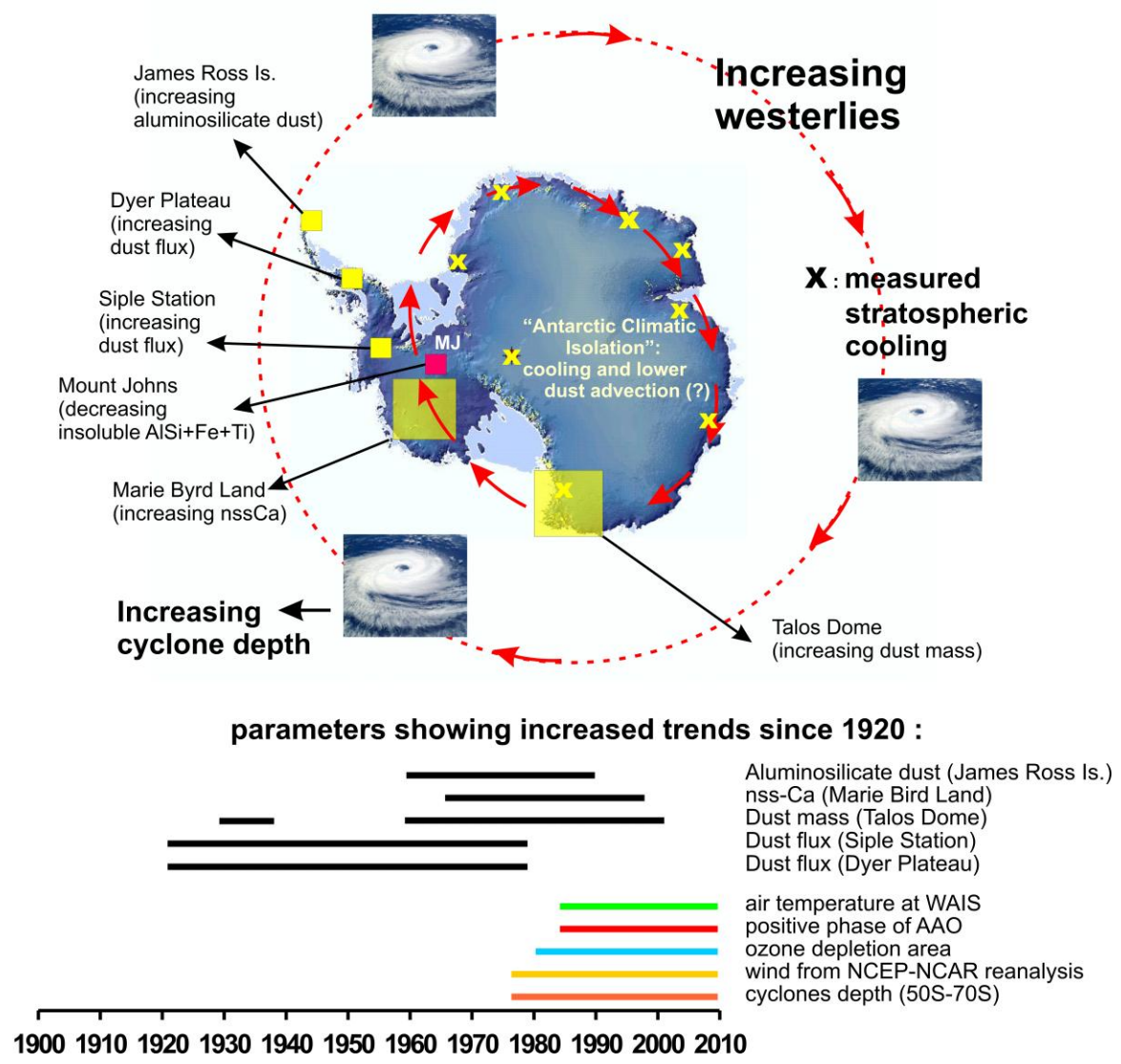

Fig. 6. Schematic summary of recently observed patterns of mineral dust deposition in western Antarctica and continental climatic changes. (Air temperature at West Antarctica Ice Sheet, WAIS, is presented in Schneider et al., 2012; geochemical data of Talos Dome in Sala et al., 2008; Marie Byrd Land in Dixon et al., 2013; James Ross Is. in McConnell et al., 2007; Dyer Plateau in Thompson et al., 1994; Siple Station in Mosley-Thompson, 1992; and Mount Johns, this study).

microparticle diameter is mainly constrained by wind and cyclone energy around Antarctica (Group 1 in the cluster analyses).

Mean microparticle diameter correlated significantly with cyclone energy (confidence level of 0.05 ) for a broad latitudinal band enclosing $30-70^{\circ} \mathrm{S}$, a region that covers the greatest fraction of dust emissions at Patagonian semi-desert (northern Patagonia, centered at $\left(44^{\circ} \mathrm{S}, 67^{\circ} \mathrm{W}\right)$ and the San Julian's Great Depression, centered at $\left(49^{\circ} \mathrm{S}, 69^{\circ} \mathrm{W}\right)$, formed by scattered dry lakes and topographic depressions). A higher Pearson's $r$ value was obtained for cyclones migrating in the $50-70^{\circ} \mathrm{S}$ belt $(r=+0.62)$. Around 26 to $38 \%$ of the diameter variability in MJ can be explained by the cyclone depth model over continental dust source regions and the Southern Ocean. Additionally, we have used quadratic models to obtain the best fit between wind intensity around Antarctic (using the DJF database) and diameter $(d)$, expressed in microm, of insoluble microparticle be $V_{\mathrm{DFJ}}\left(\mathrm{m} \mathrm{s}^{-1}\right) \sim 4.39+$ $3.62 d-0.75 d^{2}$. A very similar model was found considering the annual wind database we found $V_{\text {annual }}\left(\mathrm{m} \mathrm{s}^{-1}\right)$ $\sim 6.00+3.03 d-0.65 d^{2}$.

\section{Concluding remarks}

On long time scales (e.g., Holocene/Last Glacial), previous works (Petit et al., 1981; Deangelis et al., 1987) have inferred the wind strength on the basis of dust concentrations and diameter distributions measured in deep ice cores. These associations are based on empirical relations between the glaciological data and numerical models that may incorporate considerable uncertainties. For the last decades, in contrast, combined climate models, ground-based observations, satellite observation and annually resolved geochemical databases from ice cores have together provided a unique opportunity to improve knowledge and to directly associate the climate dynamics of the Antarctic and surrounding continents with dust microparticle sources, their time variability, and diameter distribution while deposited in the Antarctic ice sheet. This reinforces the important role of the terrigenous tracers as an important avenue to evaluate models.

Our results contrast with recently published West Antarctic ice-core dust analyses that point to strong dust enhancements from mid-20th century to the present (McConnell et 
al., 2007). In light of the results of the present investigation we may explain these differences (and other aspects of the dust transport) with the aid of the schematic scenario presented in Fig. 6. Our data show that during the ozone depletion period, dust advection to the central western Antarctic sector changed from a stable to a reducing deposition pattern. Thus suggests that climatically driven processes due to ozone depletion may act differently over different parts of the Antarctic continental scale with respect to the atmospheric transport of particulate matter. According to Thompson and Solomon (2002), recent significant tropospheric trends in Antarctica are related to trends in the lower stratospheric polar vortex that may contribute substantially to the observed cooling over eastern Antarctica and the Antarctic plateau. An example of that is the temperature decline over central and East Antarctica inferred from the Advanced Very High Resolution Radiometer (AVHRR) sensors (using the thermal infrared channel) from 1982 to 2004.

A summary of the geochemical data in West Antarctica as depicted in Fig. 6 with the Antarctic near-surface temperatures as proposed by several authors (eg.: Steig et al., 2009; O'Donnell et al., 2011; Schneider et al., 2012) clearly shows that West Antarctica experiences both elevated temperatures and shows incursions of air masses from lower latitudes, judging from the increasing content of mineral dust in recent firn/ice layers. Additionally, according to Nicolas and Bromwich (2011), the low pressures centered over the Ross Sea (as opposed to the Bellingshausen Sea) are found to be one important factor in delivering heat and moisture into West Antarctica, with consequences for surface-water mass balance. They attribute this to changes in cyclonic activity in the South Pacific sector of the Southern Ocean. Also, Schneider et al. (2012) demonstrated that trends in near surface winds and geopotential heights over the high-latitude South Pacific are consistent with recently observed impacts on regional sea ice and air temperature anomalies. An interesting aspect of Fig. 6 is that dust increases slightly precede the climatic changes. However, data reported in the literature reveal even steeper trends in dust increases since the end of the 1970s when compared to previous decades. In this context, the impact of wind intensification driven by ozone depletion or AAO phase change should be considered as an additional forcing acting in the climate system -

not necessarily the trigger of the observed dust concentration increases, but an important player to the regional environmental interpretation.
Acknowledgements. We wish to acknowledge the National Council for Research (CNPq), the Brazilian Antarctic Program (PROANTAR), who have supported this project, (grants number: 556971/2009-4 and 573720/2008-8) and the Brazilian National Institute for Science and Technology (INCT-Criosfera). All online platforms and databases used in this work: NCEP data; Halley data; South Pole data. Parts of the research were made possible by a grant from the Australian Antarctic Science Committee.

Edited by: R. Müller

\section{References}

Anderberg, M. R.: Cluster Analysis for Applications. Academic Press, 359 pp., 1973.

Arblaster, J. M. and Meehl, G. A.: Contributions of external forcings to southern annular mode trends, J. Climate, 19, 2896-2905, 2006.

Arblaster, J. M., Meehl, G. A., and Karoly, D. J.: Future climate change in the Southern Hemisphere: Competing effects of ozone and greenhouse gases, Geophys. Res. Lett., 38, L02701, doi:10.1029/2010GL045384, 2011.

Basile, I., Grousset, F. E., Revel, M., Petit, J. R., Biscaye, P. E., and Barkov, N. I.: Patagonian origin of glacial dust deposited in East Antarctica (Vostok and Dome C) during glacial stages 2, 4 and 6, Earth Planet. Sc. Lett., 146, 573-589, 1997.

Bondarenko, I., Treiger, B., VanGrieken, R., and VanEspen, P.: IDAS: A Windows based software package for cluster analysis, Spectrochim Acta B, 51, 441-456, 1996.

Bromwich, D. H., Fogt, R. L., Hodges, K. I., and Walsh, J. E.: A tropospheric assessment of the ERA-40, NCEP, and JRA-25 global reanalyses in the polar regions, J. Geophys. Res., 112, D10111, doi:10.1029/2006JD007859, 2007.

Deangelis, M., Barkov, N. I., and Petrov, V. N.: Aerosol Concentrations over the Last Climatic Cycle $(160 \mathrm{Kyr})$ from an Antarctic Ice Core, Nature, 325, 318-321, 1987.

Delworth, T. L., Broccoli, A. J., Rosati, A., Stouffer, R. J., Balaji, V., Beesley, J. A., Cooke, W. F., Dixon, K. W., Dunne, J., Dunne, K. A., Durachta, J. W., Findell, K. L., Ginoux, P., Gnanadesikan, A., Gordon, C. T., Griffies, S. M., Gudgel, R., Harrison, M. J., Held, I. M., Hemler, R. S., Horowitz, L. W., Klein, S. A., Knutson, T. R., Kushner, P. J., Langenhorst, A. R., Lee, H. C., Lin, S. J., Lu, J., Malyshev, S. L., Milly, P. C. D., Ramaswamy, V., Russell, J., Schwarzkopf, M. D., Shevliakova, E., Sirutis, J. J., Spelman, M. J., Stern, W. F., Winton, M., Wittenberg, A. T., Wyman, B., Zeng, F., and Zhang, R.: GFDL's CM2 global coupled climate models. Part I: Formulation and simulation characteristics, J. Climate, 19, 643-674, 2006.

Dibb, J., Mayewski, P. A., Buck, C. F., and Drummey, S. M.: Beta radiation from snow, Nature, 344, 6270, doi:10.1038/345025a0, 1990.

Digby, P. G. N. and Kempton, R. A.: Multivariate analysis of ecological communities, 1st edn. Chapman \& Hall, London, 80-86, 1987.

Dixon, D. A., Mayewski, P. A., Goodwin, I. D., Marshall, G. J., Freeman, R., Maasch, K. A., and Sneed, S. B.: An ice-core proxy for northerly air mass incursions into West Antarctica, Int. J. Climatol., 32, 1455-1465, doi:10.1002/Joc.2371, 2012. 
Evangelista, H. and Pereira, E. B.: Radon flux at King George Island, Antarctic Peninsula, J. Environ. Radioactiv., 61, 283-304, PiiS0265-931x(01)00137-0, 2002.

Farman, J. C., Gardiner, B. G., and Shanklin, J. D.: Large Losses of Total Ozone in Antarctica Reveal Seasonal Clox/Nox Interaction, Nature, 315, 6016, 207-210, 1985

Hall, A. and Visbeck, M.: Synchronous variability in the Southern Hemisphere atmosphere, sea ice, and ocean resulting from the annular mode, J. Climate, 15, 3043-3057, 2002.

Handl, J., Sachse, R., Jakob, D., Michel, R., Evangelista, H., Gonçalves, A. C., and Freitas, A. C.: Accumulation of ${ }^{137} \mathrm{Cs}$ in Brazilian soils and its transfer to plants under different climatic conditions, J. Environ. Radioactiv., 99, 271-287, 2008.

Hendon, H. H., Thompson, D. W. J., and Wheeler, M. C.: Australian rainfall and surface temperature variations associated with the Southern Hemisphere annular mode, J. Climate, 20, 2452-2467, 2007.

Hines, K. M., Bromwich, D. H., and Marshall, G. J.: Artificial surface pressure trends in the Ncep-Ncar reanalysis over the southern ocean and Antarctica, J. Climate, 13, 3940-3952, 2000.

Hoornaert, S., Godoi, R. H. M., and Van Grieken, R.: Elemental and single particle aerosol characterisation at a background station in Kazakhstan, J. Atmos. Chem., 48, 301-315, 2004.

Jones, A. E. and Shanklin, J. D.: Continued Decline of Total Ozone over Halley, Antarctica, since 1985, Nature, 376, 409-411, 1995.

Kalnay, E., Kanamitsu, M., Kistler, R., Collins, W., Deaven, D., Gandin, L., Iredell, M., Saha, S., White, G., Woollen, J., Zhu, Y., Chelliah, M., Ebisuzaki, W., Higgins, W., Janowiak, J., Mo, K. C., Ropelewski, C., Wang, J., Leetmaa, A., Reynolds, R., Jenne, R., and Joseph, D.: The NCEP/NCAR 40-year reanalysis project, B. Am. Meteorol. Soc., 77, 437-471, 1996.

Keeley, S. P. E., Gillett, N. P., Thompson, D. W. J., Solomon, S., and Forster, P. M.: Is Antarctic climate most sensitive to ozone depletion in the middle or lower stratosphere?, Geophys. Res. Lett., 34, L22812. doi 10.1029/2007g1031238, 2007.

Law, R., Simmonds, I., and Budd, W. F.: Application of an Atmospheric Tracer Model to High Southern Latitudes, Tellus B, 44, 358-370, 1992.

Lefebvre, W., Goosse, H., Timmermann, R., and Fichefet, T.: Influence of the Southern Annular Mode on the sea ice-ocean system, J. Geophys. Res., 109, C09005, doi:10.1029/2004JC002403, 2004.

Lenton, A., Codron, F., Bopp, L., Metzl, N., Cadule, P., Tagliabue, A., and Le Sommer, J.: Stratospheric ozone depletion reduces ocean carbon uptake and enhances ocean acidification, Geophys. Res. Lett., 36, L12606. doi:10.1029/2009GL038227, 2009.

Li, F. Y., Ginoux, P., and Ramaswamy, V.: Distribution, transport, and deposition of mineral dust in the Southern Ocean and Antarctica: Contribution of major sources, J. Geophys. Res., 113, D10207, doi:10.1029/2007JD009190, 2008.

Li, F. Y., Ginoux, P., and Ramaswamy, V.: Transport of Patagonian dust to Antarctica, J. Geophys. Res., 115, D18217, doi:10.1029/2009JD012356, 2010.

Lim, E.-P. and Simmonds, I.: Southern Hemisphere winter extratropical cyclone characteristics and vertical organization observed with the ERA-40 reanalysis data in 1979-2001, J. Climate, 20, 2675-2690, 2007.

Marshall, G. J.: Trends in the Southern Annular Mode from observations and reanalyses, J. Climate, 16, 4134-4143, 2003.
Marshall, G. J.: Half-century seasonal relationships between the Southern Annular Mode and Antarctic temperature, Int. J. Climatol., 27, 373-383, 2007.

McConnell, J. R., Aristarain, A. J., Banta, J. R., Edwards, P. R., and Simoes, J. C.: 20th-Century doubling in dust archived in an Antarctic Peninsula ice core parallels climate change and desertification in South America, P. Natl. Acad. Sci. USA, 104, 57435748, doi:10.1073/pnas.0607657104, 2007.

Monaghan, A. J., Bromwich, D. H., and Wang, S.-H.: Recent trends in Antarctic snow accumulation from Polar MM5 simulations, Philos. T. Roy. Soc. A, 364, 1683-1708, 2006a.

Monaghan, A. J., Bromwich, D. H., Fogt, R. L., Wang, S. H., Mayewski, P. A., Dixon, D. A., Ekaykin, A., Frezzotti, M., Goodwin, I., Isaksson, E., Kaspari, S. D., Morgan, V. I., Oerter, H., Van Ommen, T. D., Van der Veen, C. J., and Wen, J. H.: Insignificant change in Antarctic snowfall since the International Geophysical Year, Science, 313, 827-831, 2006b.

Mosley-Thompson, E.: Paleoenvironmental conditions in Antarctica since A.D. 1500: Ice core evidence, in Climate since A.D. 1500, edited by: Bradley, R. S. and Jones, P. D., 572-591, Routledge, London, 1992.

Müller, R.: A brief history of stratospheric ozone research, Meteorol. Z., 18, 3-24, doi:10.1127/0941-2948/2009/353, 2009.

Nicolas, J. P. and Bromwich, D. H.: Climate of West Antarctica and Influence of Marine Air Intrusion, J. Climate, 24, 49-67, 2011.

O’Donnell, R., Lewis, N., McIntyre, S., and Condon, J.: Improved Methods for PCA-Based Reconstructions: Case Study Using the Steig et al. (2009) Antarctic Temperature Reconstruction, J. Climate, 24, 2099-2115, doi:10.1175/2010JCLI3656.1, 2011.

Parish, T. R. and Bromwich, D. H.: Reexamination of the nearsurface airflow over the Antarctic continent and implications on atmospheric circulations at high southern latitudes, Mon. Weather Rev., 135, 1961-1973, doi:10.1175/Mwr3374.1, 2007.

Petit, J. R., Briat, M., and Royer, A.: Ice-Age Aerosol Content from East Antarctic Ice Core Samples and Past Wind Strength, Nature, 293, 391-394, 1981.

Pezza, A. B., Durrant, T., Simmonds, I., and Smith, I.: Southern Hemisphere synoptic behavior in extreme phases of SAM, ENSO, sea ice extent and southern Australia rainfall, J. Climate, 21, 5566-5584, 2008.

Prospero, J. M., Ginoux, P., Torres, O., and Nicholson, S. E.: Environmental characterization of global sources of atmospheric soil dust identified with the Nimbus 7 Total Ozone Mapping Spectrometer (TOMS) absorbing aerosol product, Rev. Geophys., 40, 1002, doi:10.1029/2000RG000095, 2002.

Rodriguez, I., Gali, S., and Marcos, C.: Atmospheric inorganic aerosol of a non-industrial city in the centre of an industrial region of the North of Spain, and its possible influence on the climate on a regional scale, Environ. Geol., 56, 1551-1561, doi:10.1007/s00254-008-1253-9, 2009.

Sala, M., Delmonte, B., Frezzotti, M., Proposito, M., Scarchilli, C., Maggi, V., Artioli, G., Dapiaggi, M., Marino, F., Ricci, P. C., and De Giudici, G.: Evidence of calcium carbonates in coastal (Talos Dome and Ross Sea area) East Antarctica snow and ?rn: Environmental and climatic implications, Earth Planet. Sci. Lett., 271, 43-52, 2008.

Schneider, D. P., Deser, C., and Okumura, Y.: An assessment and interpretation of the observed warming of West Antarctica in the austral spring, Clim. Dynam., 38, 323-347, 2012. 
Sen Gupta, A. S. and England, M. H.: Coupled ocean-atmosphereice response to variations in the southern annular mode, J. Climate, 19, 4457-4486, 2006.

Shindell, D. T., Rind, D., and Lonergan, P.: Increased polar stratospheric ozone losses and delayed eventual recovery owing to increasing greenhouse-gas concentrations, Nature, 392, 589-592, doi:10.1038/33385, 1998.

Simmonds, I.: Modes of atmospheric variability over the Southern Ocean, J. Geophys. Res., 108, 8078, doi:10.1029/2000JC000542, 2003.

Simmonds, I. and Keay, K.: Mean Southern Hemisphere extratropical cyclone behavior in the 40-year NCEP-NCAR reanalysis, J. Climate, 13, 873-885, 2000.

Simmonds, I. and King, J. C.: Global and hemispheric climate variations affecting the Southern Ocean, Antarctic Science, 16, 401413, 2004.

Simmonds, I., Burke, C., and Keay, K.: Arctic Climate Change as Manifest in Cyclone Behavior, J. Climate, 21, 5777-5796, doi:10.1175/2008JCLI2366.1, 2008.

Solomon, S.: Stratospheric ozone depletion: A review of concepts and history, Rev. Geophys., 37, 275-316, doi:10.1029/1999RG900008, 1999.

Solomon, S., Garcia, R. R., Rowland, F. S., and Wuebbles, D. J.: On the depletion of Antarctic ozone, Nature, 321, 755-758, doi:10.1038/321755a0, 1986.

Steig, E. J., Schneider, D. P., Rutherford, S. D., Mann, M. E., Comiso, J. C., and Shindell, D. T.: Warming of the Antarctic ice-sheet surface since the 1957 International Geophysical Year, Nature, 457, 459-454, doi:10.1038/Nature07669, 2009.

Swart, N. C. and Fyfe, J. C.: Observed and simulated changes in the Southern Hemisphere surface westerly wind-stress, Geophys. Res. Lett., 39, L16711, doi:10.1029/2012gl052810, 2012.
Thompson, D. W. J. and Solomon, S.: Interpretation of recent Southern Hemisphere climate change, Science, 296, 895-899, 2002.

Thompson, D. W. J., Wallace, J. M., and Hegerl, G. C.: Annular modes in the extratropical circulation. Part II: Trends, J. Climate, 13, 1018-1036, 2000.

Thompson, L. G., Peel, D. A., Mosley-Thompson, E., Mulvaney, R., Dal, J., Lin, P. N., Davis, M. E., and Raymond, C. F.: Climate since AD 1510 on Dyer Plateau, Antarctic Peninsula: evidence for recent climate change, Ann. Glaciol., 20, 420-426, 1994.

Turner, J., Comiso, J. C., Marshall, G. J., Lachlan-Cope, T. A., Bracegirdle, T., Maksym, T., Meredith, M. P., Wang, Z. M., and Orr, A.: Non-annular atmospheric circulation change induced by stratospheric ozone depletion and its role in the recent increase of Antarctic sea ice extent, Geophys. Res. Lett., 36, L08502, doi:10.1029/2009g1037524, 2009.

Van Espen P. and Janssens, K.: Spectrum Evaluation, in: Handbook of X-ray Spectrometry, edited by: Van Grieken, R., Marcowicz, A., and Dekker, M., New York, (ISBN 0-8247-8483-9), 1992.

Visbeck, M.: A Station-Based Southern Annular Mode Index from 1884 to 2005, J. Climate, 22, 940-950, 2009.

Vogel, B., Feck, T., and Grooß, J. U.: Impact of stratospheric water vapor enhancements caused by $\mathrm{CH}_{4}$ and $\mathrm{H}_{2} \mathrm{O}$ increase on polar ozone loss, J. Geophys. Res., 116, D05301, doi:10.1029/2010jD014234, 2011.

Zepp, R. G., Callaghan, T. V., and Erickson, D. J.: Effects of enhanced solar ultraviolet radiation on biogeochemical cycles, J. Photoch. Photobio. B, 46, 69-82, 1998. 